\title{
Modifications in climate suitability for wine production of Romanian wine regions as a result of climate change
}

\author{
Liviu Mihai Irimia ${ }^{1}$, Cristian Valeriu Patriche ${ }^{2}$, Bogdan Roşca $^{2}$, and Valeriu V. Cotea ${ }^{1}$ \\ ${ }^{1}$ University of Agriculture Sciences, Faculty of Horticulture, 700505 Iasi, Romania \\ ${ }^{2}$ Romanian Academy, Iaşi Branch, Geography Group, 700505 Iasi, Romania
}

\begin{abstract}
The aim of this study is to reveal the shifts in climate suitability for wine production affecting Romanian wine growing regions. For this, we analyzed the spatial distribution over Romanian territory of the oenoclimate aptitude index (IAOe) for the 1961 to 1990 and 1991 to 2013 time periods. The IAOe has been calculated based on gridded data at $10 \times 10 \mathrm{~km}$ resolution of average daily temperature, precipitation and sunshine duration between 1961-2013, originating from about 150 weather stations across Romanian territory and recorded in the ROCADA database. The study reveals: northward shifts and to higher altitudes of suitability for wine production; the appearance of new areas suitable for wine production; the expansion or the shrinkage of the current areas suitable for wine production; shifts in classes of suitability for wine production in the current wine regions and appearance of premises of replacing their specific varieties and traditional wine type production; the tendency to level climate suitability at regional scale by diminishing suitability for white wines and replacing it with climate suitability for red wines. The study provides a solid support for developing strategies to adapt Romanian viticulture to climate change.
\end{abstract}

\section{Introduction}

Climate suitability for wine production determines the possibility of grapevine growing, wine grape variety assortments of wine regions and their types of wine production. Climate suitability is a stable trait of a wine area over time, with minor variations from year to year, and yet unable to modify the specific type of wine production of a wine region. In the climate change context [1] this trait of wine regions changes significantly leading to important consequences: modification of grapevine phenology [2]; earlier maturation of grapes, altering their color and aromatic profile [3]; higher alcoholic potential and lower total acidity of grape juice [4]; changes in the consecrated sensory profile of wines [5].

Changing climate suitability for wine production manifests globally, with detrimental consequences in the warm Mediterranean areas [6] and positive consequences for northern wine regions with cooler climate, which can diversify their types of wine production. Projections based on climate models predict the expansion of suitable area for grapevine growing beyond the northern and southern limits of vine area at global level, as well as shifts to higher altitudes [7-9].

The impact of climate change on viticulture is also of great interest for Romania, a traditional viticultural country with a wine area of about 197,000 ha and an annual wine production of about 6 million $\mathrm{Hl}$ [10]. In Romania the wine production has local specificity generated by: autochtonous vinifera wine grape varieties; traditional grapevine training systems; specific wine types. These features have strengthened over the centuries and have become authentic elements for Romanian vineyards that are trying to be kept under the climate change.
Romania's wine-growing area is structured in eight large wine-growing regions including 141 wine growing centers (vine plantations around a locality). The eight Romanian wine regions have particular environmental characteristics, generated by latitude, topography, proximity to the Carpathian Mountains situated in the center of the country, proximity to the Black Sea bordering Romania to SE, or proximity to the Danube River bordering southern limit of the country.

The manifestation of climate change over Romania territory has been studied by Romanian climatologists in recent years in all its aspects [11-15]. The main developments are: increased summer temperatures; precipitation stability; increasing sunshine duration; increasing air temperatures during January and February; diminishing numbers of days with frosts; increasing frequency and intensity of extreme phenomena.

As a result of these developments climatic parameters specific to Romanian vineyards have changed [16] determining changes in climate suitability for wine production at vineyards level [17]. The impact of climate change on viticulture, still less studied at the national level, indicates: earlier bud-burst; shortening of stages of annual growth cycle; early grapes ripening; diminishing grapes total acidity and increasing sugar content. As consequences of these developments, cool climate vineyards have already introduced wine grape varieties for red wines, while the southern, warmer ones have introduced wine grape varieties that better preserve grapes acidity, such as Rhine Riesling or even varieties such as Syrah, specific to Mediterranean wine regions.

The purpose of this study is to find out the changes in climate suitability for wine production of Romanian wine 


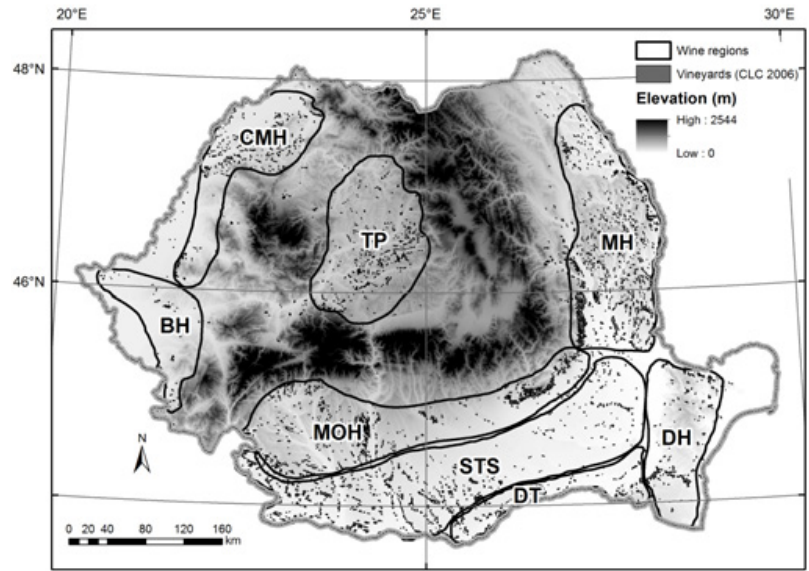

Figure 1. Location of Romanian wine growing regions: TP Transilvania Plateu; MH - Moldavia Hills; MOH - Muntenia and Oltenia Hills; BH - Banat Hills; CMH - Crişana and Maramureş Hills; DH - Dobrogea Hills; DT - Danube Terraces; STS Southern Terrains and Sands.

regions as a result of climate change. Climatic suitability is expressed through the IAOe oenoclimate aptitude index [18], an index generally used in Romanian viticulture for vineyards climate analysis. It is distinguished from heat summation indices in that it includes, besides the influence of temperature on the grapevine, the influence of sunshine duration and precipitation during the growing season, which provides a much higher accuracy in representation of climate suitability. Its values reveal the conceivable wine type production in an area, especially the possibility of obtaining red wines. This index correlates with the grapes anthocyanins content at the Cabernet Sauvignon variety.

\section{Material and method}

Romania is located in temperate continental climate Dfb and Dfa zone [19], between $43^{\circ} 37^{\prime}-48^{\circ} 15^{\prime} \mathrm{N}$ lat. and $20^{\circ} 15^{\prime}-29^{\circ} 44^{\prime}$ E long (Fig. 1).

The eight Romanian wine growing areas are: Transylvania Plateu (TP); Moldavia Hills (MH); Muntenia and Oltenia Hills (MOH); Banat Hills (BH); Crişana and Maramureş Hills (CMH); Dobrogea Hills (DH); Danube Terraces (DT); Southern Terrains and Sands (STS). The analysis regards the entire area of each wine growing region, as they were delineated on Romania map in the Fig. 1. The map of wine growing centers and vineyards location within Romanian wine growing regions is extracted from the Corine Land Cover Database 2006 Europe [20].

The climate data base for this study is represented by gridded data at 0.1 degrees' resolution $(10 \times$ $10 \mathrm{~km}$ ) of daily average temperature, precipitation and sunshine duration during the 1961-2013 extracted from the ROCADA database [21]. These parameters have been used to calculate the sum of active temperatures ( $\Sigma$ ta, $\left.{ }^{\circ} \mathrm{C}\right)$, precipitation $(\mathrm{PP}, \mathrm{mm})$ and actual sunshine duration (ASD, hours) during the growing season (April $1^{\text {st }}$ to September $30^{\text {th }}$ ), needed to compute the IAOe index for the 1961 to 1990 and for the 1991 to 2013 time periods. The IAO was computed based on [18] formula (1):

$$
I A O e=A S D+\Sigma t_{a}-(P P-250)
$$

where: $A S D=$ actual sunshine duration (hours, April $1^{\text {st }}$ to September $\left.30^{\text {th }}\right) ; \Sigma t_{a}=$ the sum of active temperatures (sum of daily average temperatures $\geq 10^{\circ} \mathrm{C} /$ April $1^{\text {st }}$ to September $\left.30^{\text {th }}\right) ; P P=$ precipitation $\left(\mathrm{mm}\right.$, April $1^{\text {st }}$ to September $\left.30^{\text {th }}\right) ; 250=(\mathrm{mm})$ minimum precipitation required for unirrigated grapevine growing. For situations where PP $<250 \mathrm{~mm}$, the IAOe is computed as the sum of ASD and $\Sigma \mathrm{t}_{\mathrm{a}}[18]$.

Within Romanian wine regions the IAOe values vary between 3793 and $>5200$ units, with values higher than 5200 characterizing wine areas at the southern limit of the country producing mainly table grapes [22]. In this study, the IAOe is classified according to [23] as follows: IAOe $<3793=$ unsuitable for grapevine growing (UNS); IAOe $=3793-4300=$ suitable for white table wines, sparkling wines, wines for distillates (WTW $+\mathrm{SW}+\mathrm{WD}$ ); IAOe $=4301-4600=$ suitable for quality white wines and red table wines $(\mathrm{QWW}+\mathrm{RTW})$; IAOe $>4600=$ suitabile for quality red wines (QRW).

The study involves the analysis at Romanian wine growing regions level of averages and suitability for wine production of the $\Sigma \mathrm{t}_{a}, \mathrm{PP}, \mathrm{ASD}$ and IAOe for two time periods considered to have different climatic characteristics: 1961-1990 and 1991-2013. In the case of IAOe the changes in suitability and spatial distribution within the eight wine growing regions are analyzed.

\section{Results}

\subsection{Changes in temperature, precipitation and sunshine duration within Romanian wine growing regions between 1961-2013}

According to the data in Tables 1 and 2, within the eight Romanian wine growing regions, during the period 1961-2013, there were recorded important increases in temperature and sunshine duration, amid of a relative stability of precipitation during the growing season. According to previous research on grapevine relationships with environmental factors, these are the main determinants of grapes quality [24,25]. Changing their values automatically leads to changes in growing and fruiting conditions for the grapevine with consequences on chemical composition of grapes and implicitly of wines.

The data presented in Table 1 reveals that the $\Sigma$ ta $\left({ }^{\circ} \mathrm{C}\right)$ average increased at the Romanian viticulture area level by $198^{\circ} \mathrm{C}$, from $3003{ }^{\circ} \mathrm{C}$ between $1961-1990$ to $3201{ }^{\circ} \mathrm{C}$ between 1991-2013. According to our data the highest increases in $\Sigma$ ta occur in the western part of Romania where the $\mathrm{CMH}$ and $\mathrm{BH}$ wine regions are located and these increases are of $+213^{\circ} \mathrm{C}$ for the $\mathrm{CMH}$ and of $+208^{\circ} \mathrm{C}$ for the $\mathrm{BH}$. These outcomes are consistent with the data reported by [15] for this part of Romania, but also with the ones revealed by a regional study covering the western part of Romania as well carried out in Hungary by [26]. The lowest temperature increases are recorded in the wine regions from the southern part of Romania $\left(+187^{\circ} \mathrm{C}\right.$ for the $\mathrm{MOH}$ and $190^{\circ} \mathrm{C}$ for the STS), which during the $1961-$ 1990 were the warmest.

Equally important increases are also found in the case of ASD (Table 2), an extremely important factor for anthocyanins accumulation in grapes at the red wine grape varieties [25]. Our data reveal increases of +76 hours to +102 hours for the April 1st to September 
Table 1. The sum of active temperatures for Romanian wine regions during the 1961-1990 (61/90) and the 1991-2013 (91/13) time periods. Values computed based on ROCADA climatic data base [21].

\begin{tabular}{|c|c|c|c|c|c|}
\hline \multirow{2}{*}{ Wine region } & \multicolumn{2}{|c|}{$\Sigma$ ta $\left({ }^{\circ} \mathbf{C}\right)$} & \multirow{2}{*}{ Difference $( \pm)$} & \multicolumn{2}{|c|}{ Average for the growing season $\left({ }^{\circ} \mathbf{C}\right)$} \\
\cline { 2 - 4 } & $\mathbf{6 1 / 9 0}$ & $\mathbf{9 0 / 1 3}$ & & $\mathbf{6 1 / 9 0}$ & $\mathbf{9 0 / 1 3}$ \\
\hline TP & 2590 & 2789 & +199 & 14.38 & 15.49 \\
\hline MH & 2961 & 3154 & +193 & 16.45 & 17.55 \\
\hline MOH & 3005 & 3192 & +187 & 16.69 & 17.73 \\
\hline BH & 2999 & 3207 & +208 & 16.66 & 17.81 \\
\hline CMH & 2836 & 3049 & +213 & 15.75 & 16.93 \\
\hline DH & 3109 & 3311 & +202 & 17.27 & 18.39 \\
\hline DT & 3269 & 3466 & +197 & 18.16 & 19.25 \\
\hline STS & 3251 & 3441 & +190 & 18.06 & 19.11 \\
\hline Averages & $\mathbf{3 0 0 3}$ & $\mathbf{3 2 0 1}$ & $+\mathbf{1 9 8}$ & $\mathbf{1 6 . 6 7}$ & $\mathbf{1 7 . 4 3}$ \\
\hline
\end{tabular}

Table 2. Precipitation during the growing season (PP) and sunshine duration (ASD) for Romanian wine regions, during the 1961-1990 (61/90) and 1991-2013 (91/13). Values computed based on ROCADA data base [21].

\begin{tabular}{|l|c|c|c|c|c|c|}
\hline \multirow{2}{*}{ Wine region } & \multicolumn{2}{|c|}{ PP $(\mathbf{m m})$} & \multicolumn{2}{c|}{ ASD (hours) } & \multicolumn{2}{c|}{ Differences } \\
\cline { 2 - 7 } & $\mathbf{6 1 / 9 0}$ & $\mathbf{9 0 / 1 3}$ & $\mathbf{6 1 / 9 0}$ & $\mathbf{9 0 / 1 3}$ & PP & ASD \\
\hline TP & 400 & 413 & 1307 & 1409 & +13 & +102 \\
\hline MH & 354 & 354 & 1418 & 1515 & 0 & +98 \\
\hline MOH & 383 & 392 & 1433 & 1509 & +9 & +76 \\
\hline BH & 382 & 385 & 1414 & 1493 & +3 & +79 \\
\hline CMH & 377 & 380 & 1414 & 1515 & +3 & +101 \\
\hline DH & 239 & 266 & 1510 & 1607 & +27 & +97 \\
\hline DT & 302 & 320 & 1518 & 1609 & +17 & +91 \\
\hline STS & 313 & 321 & 1519 & 1606 & +8 & +87 \\
\hline Averages & $\mathbf{3 4 4}$ & $\mathbf{3 5 4}$ & $\mathbf{1 4 4 2}$ & $\mathbf{1 5 3 3}$ & $+\mathbf{1 0}$ & $+\mathbf{9 1}$ \\
\hline
\end{tabular}

30th in ASD between 1961-2013, with minima in the $\mathrm{MOH}$ wine region and maxima in TP wine region, the last one being known as the coldest and poorest in heliothermal resources of all Romanian wine regions [27]. These sunshine increases, with an average of +91 hours at Romanian wine regions level, are suitable for the accumulation of organic compounds in grapes and can be considered to be a factor sustaining grapes quality at red winegrape varieties.

Precipitation dwithin a wide range,uring the growing season (April $1^{\text {st }}$ - September $30^{\text {th }}$ ) slightly increased between 1961-2013, with an average of about $+10 \mathrm{~mm}$ at Romanian wine growing regions level (Table 2). However, the extreme values fall within a wide range, ranging from a minimum of $0 \mathrm{~mm}$ for the $\mathrm{MH}$ wine region to a maximum of $+27 \mathrm{~mm}$ for the $\mathrm{DH}$ wine region. As compared to grapevine need of precipitation during the growing season [22], one can consider that by the increase of $27 \mathrm{~mm}$, the PP for the DH wine region exceeds the threshold showing the need of grapevine irrigation $(\geq 250 \mathrm{~mm})$. Taking into account the increase of temperatures during the same time period for the DH wine region, and implicitly the intensification of evapotranspiration as a consequence of this phenomenon [28], this increase may not meet the water needs of the grapevine. As for the other winegrowing regions, the increase in the rainfall volume is insignificant. Maintaining the perceived trends is likely to lead to increased in aridity and to the need for grapevine irrigation in the future, especially for the $\mathrm{MH}$, $\mathrm{BH}, \mathrm{CMH}$ regions characterized by the lowest rainfall
Table 3. Averages of oenoclimate aptitude index IAOe for the Romanian wine region, during the 1961-1990 (61/90) and 19912013 (91/13). Values computed based on ROCADA climatic data base [21].

\begin{tabular}{|l|c|c|c|c|c|c|}
\hline & \multicolumn{6}{|c|}{ IAOe } \\
\hline \multirow{2}{*}{ Wine region } & \multicolumn{2}{|c|}{ Min } & \multicolumn{2}{c|}{ Max } & \multicolumn{2}{c|}{ Mean } \\
\cline { 2 - 7 } & $\mathbf{6 1 / 9 0}$ & $\mathbf{9 0 / 1 3}$ & $\mathbf{6 1 / 9 0}$ & $\mathbf{9 0 / 1 3}$ & $\mathbf{6 1 / 9 0}$ & $\mathbf{9 0 / 1 3}$ \\
\hline TP & 2815 & 3039 & 4147 & 4447 & 3798 & 4011 \\
\hline MH & 2863 & 3132 & 4714 & 5004 & 4249 & 4537 \\
\hline MOH & 3041 & 3313 & 4814 & 5071 & 4345 & 4599 \\
\hline BH & 3477 & 3761 & 4471 & 4775 & 4275 & 4561 \\
\hline CMH & 3089 & 3371 & 4383 & 4702 & 4134 & 4446 \\
\hline DH & 3870 & 4125 & 4829 & 5106 & 4625 & 4896 \\
\hline DT & 4480 & 4761 & 4884 & 5144 & 4736 & 5005 \\
\hline STS & 4469 & 4722 & 4937 & 5203 & 4708 & 4978 \\
\hline Averages & $\mathbf{3 5 1 3}$ & $\mathbf{3 7 7 8}$ & $\mathbf{4 6 4 7}$ & $\mathbf{4 9 3 1}$ & $\mathbf{4 3 5 8}$ & $\mathbf{4 6 2 9}$ \\
\hline Differences & \multicolumn{2}{|c|}{$+\mathbf{2 6 5}$} & $+\mathbf{2 8 4}$ & \multicolumn{3}{|c|}{$+\mathbf{2 7 1}$} \\
\hline
\end{tabular}

increases and highest increases in heliothermal resources (Tables 1 and 2).

\subsection{Changes in IAOe values within the Romanian wine regions between 1961-2013}

Changes in the multi-annual averages of the $\Sigma$ ta, PP and ASD between 1961-2013 led to changes in the multiannual averages of the oenoclimate aptitude index IAOe, which reveals the suitability of vineyards climate for different types of wine production. During the 1961-2013 at Romanian wine regions level the IAOe values increased by +271 units, with maxima of +312 units for the $\mathrm{CMH}$ wine region and minima of +254 units for the $\mathrm{MOH}$ wine region. With these increases the average value of the IAOe at Romania wine regions level passes from a value showing the suitability for quality white wines and red table wines to a value (4629 units) revealing the suitability for quality red wines.

Although high, the IAOe Min for the TP, MH, $\mathrm{MOH}, \mathrm{BH}$ and $\mathrm{CMH}$ is still unsuitable for grapevine growing (Table 3), revealing the year-to-year variability and inconsistency of climate suitability for the wine production specific to temperate continental climate which characterizes this part of Europe and which naturally, leads to better or worse vintages. As opposed to the Min for the most wine regions, the IAOe Mean and Max have passed to a higher suitability class for the wine production. In the case of DH, DT, STS, MOH and $\mathrm{MH}$ wine regions, where the past IAOe Max was already suitable for red 


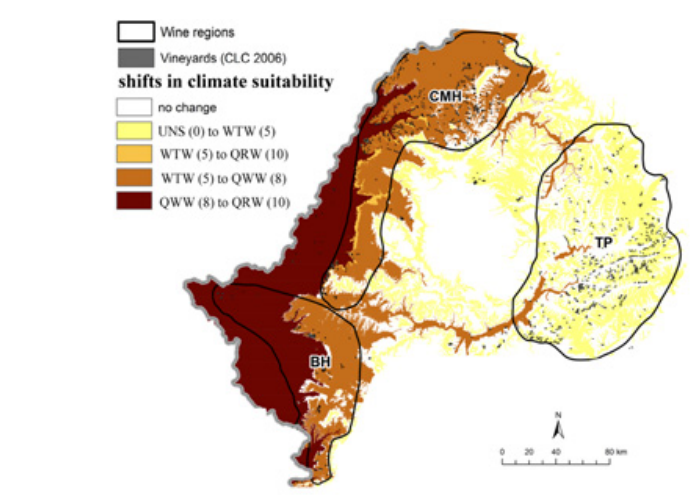

a.

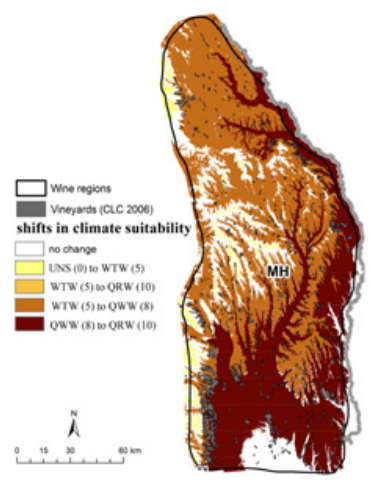

b.

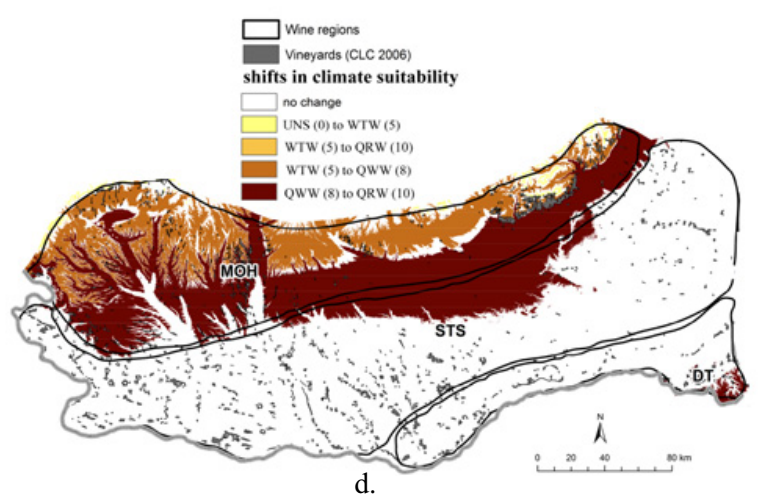

Figure 2. Shifts occurred in the spatial distribution of the IAOe suitability within Romania wine regions between 1961-2013: a. shifts in the $\mathrm{BH}, \mathrm{CMH}$ and TP wine regions; b. shifts in $\mathrm{MH}$ wine region; c. shifts in $\mathrm{DH}$ wine region; d. shifts in the $\mathrm{MOH}$, STS and DT wine regions.

wine production, the current Max maintains in the same suitability class but with higher values (Table 4). This indicates a climate evolution towards a predominance of suitability for the red wine production in Romania as well, which corresponds to the predictions of climatologists who studied the perspectives of climate suitability for wine production in the context of climate change for certain regions from the central and eastern part of Europe [26, $29,30]$.

\subsection{Modifications in climate suitability for wine production within Romanian wine regions between 1961-2013}

Analyzing the spatial distribution of changes occurred in climate suitability for wine production of Romanian wine regions, there are major changes in all of them, as well as an expansion of the area suitable for grapevine growing (Fig. 2). Climate suitability massively expands within
Table 4. Climate suitability types for wine production for Romanian wine regions during the 1961-1990 (61-90) and 1991-2013 (90-13), depending on the IAOe averages for the two time periods*.

\begin{tabular}{|l|c|c|c|c|c|c|}
\hline \multirow{3}{*}{ Wine region } & \multicolumn{6}{|c|}{ Climate suitability types according } \\
to IAOe values \\
\cline { 2 - 7 } & \multicolumn{2}{|c|}{ Min } & \multicolumn{3}{c|}{ Max } & \multicolumn{2}{c|}{ Mean } \\
\cline { 2 - 7 } & $\mathbf{6 1 / 9 0}$ & $\mathbf{9 0 / 1 3}$ & $\mathbf{6 1 / 9 0}$ & $\mathbf{9 0 / 1 3}$ & $\mathbf{6 1 / 9 0}$ & $\mathbf{9 0 / 1 3}$ \\
\hline TP & UNS & UNS & WTW & QWW & WTW & 4011 \\
\hline MH & UNS & UNS & QRW & QRW & WTW & QWW \\
\hline MOH & UNS & UNS & QRW & QRW & QWW & QWW \\
\hline BH & UNS & UNS & QWW & QRW & WTW & QWW \\
\hline CMH & UNS & UNS & QWW & QRW & WTW & QWW \\
\hline DH & WTW & WTW & QRW & QRW & QRW & QRW \\
\hline DT & QWW & QRW & QRW & QRW & QRW & QRW \\
\hline STS & QWW & QRW & QRW & QRW & QRW & QRW \\
\hline
\end{tabular}

$* \mathrm{UNS}=$ unsuitable for grapevine growing; WTW = suitable for white table wines, sparkling wines, wines for distillates; QWW = suitable for quality white wines and red table wines; $\mathrm{QRW}=$ suitable for quality red wines.

Transylvania Plateau where the TP wine region is located (Fig. 2a) and to a less extent within Moldavia Plateau, where the $\mathrm{MH}$ wine region is located (Fig. 2b). Also in the Transylvania Plateau suitable conditions for the RTW production occur, both in the traditional wine production area and outside it, on the low valleys of the main rivers. In all the other wine regions except the extreme southern ones (DT and STS) there are major shifts in spatial distribution of suitability classes: in the $\mathrm{CMH}$ and $\mathrm{BH}$ from the western part of Romania, the passage of climate suitability of the traditional areas from QWW to QRW and also the enlargement of this new climate suitability type to the entire Western Plain, far beyond the traditional winegrowing areas can be observed (Fig. 2a). What is more in the $\mathrm{CMH}$ wine region on a narrow band on the slopes of the Western Hills, a shift from the climate suitability for WTW (the lowest suitability level) to the suitability for QRW (the highest suitability level) can be observed. This evolution is validated by the initiation of the QRW production in the area during the last decade. In the $\mathrm{MH}, \mathrm{MOH}$ and $\mathrm{DH}$ wine regions, climate suitability for wine production expanded and covered the whole area: the initial climate suitability types passed to an upper suitability type, while the areas unsuitable for the wine production in the past became climatic suitable for WTW production (Figs. 2b, 2c, 2d). These shifts are revealed by the current IAOe averages for the wine growing centers (WGC) encompassed by the eight Romanian wine regions (Table 5).

Depending on their location on latitude and altitude, the IAOe values for the WGC differ from one another, being in some situations far beyond the region's IAOe average. According to our research (unpublished data) this is due to a specific local climate, characterized by higher or lower precipitation volume than the average one for the region. It is the case of Lechinţa and Bistriţa WGC in the TP where the precipitations diminished as compared to the increases recorded in all other WGC in the same region; or the Murfatlar and Medgidia WGC in the DH, where, on the contrary, rainfall has increased well above the region's average, which is reflected in the particular values of IAOe. This fact is directly related to the spatial variation of climate in the context of climate change. It is 
Table 5. Averages and differences for the oenoclimate aptitude index (IAOe) for some Romanian wine growing centers (WGC) for the 1961-1990 (61/90) and 1991-2013 (91/13) time periods. Values were computed based on gridded data at $10 \times 10 \mathrm{~km}$ resolution of temperature, precipitation and sunshine duration extracted from the ROCADA climatic data base [21].

\begin{tabular}{|c|c|c|c|c|}
\hline \multirow[b]{2}{*}{ Wine region } & \multirow[b]{2}{*}{ WGC } & \multicolumn{2}{|c|}{ IAOe } & \multirow[b]{2}{*}{$\begin{array}{c}\text { Difference } \\
( \pm)\end{array}$} \\
\hline & & $61 / 90$ & $91 / 13$ & \\
\hline \multirow{4}{*}{ TH } & Lechinţa & 3892 & 4221 & +329 \\
\hline & Turda & 3894 & 4172 & +278 \\
\hline & Jidvei & 3983 & 4269 & +286 \\
\hline & Blaj & 3991 & 4282 & +291 \\
\hline \multirow{6}{*}{ MH } & Bohotin & 4346 & 4653 & +307 \\
\hline & Avereşti & 4155 & 4459 & +304 \\
\hline & Huşi & 4436 & 4741 & +305 \\
\hline & Panciu & 4108 & 4397 & +289 \\
\hline & Odobeşti & 4333 & 4614 & +281 \\
\hline & Coteşti & 4244 & 4519 & +275 \\
\hline \multirow{5}{*}{ МOH } & Pietroasele & 4066 & 4338 & +272 \\
\hline & Tohani & 4156 & 4401 & +245 \\
\hline & Urlaţi & 4398 & 4634 & +236 \\
\hline & Halânga & 4647 & 4914 & +267 \\
\hline & Drăgăşani & 4560 & 4819 & +259 \\
\hline \multirow{2}{*}{ BH } & Teremia & 4471 & 4775 & +304 \\
\hline & Recaş & 4339 & 4626 & +287 \\
\hline \multirow{3}{*}{ CMH } & Sanislău & 4250 & 4548 & +298 \\
\hline & Valea lui Mihai & 4288 & 4586 & +298 \\
\hline & Diosig & 4365 & 4671 & +306 \\
\hline \multirow{3}{*}{ DH } & Măcin & 4637 & 4913 & +276 \\
\hline & Tulcea & 4766 & 5039 & +273 \\
\hline & Murfatlar & 4757 & 5025 & +255 \\
\hline \multirow{2}{*}{ TH } & Ostrov & 4746 & 5010 & +264 \\
\hline & Greaca & 4668 & 4933 & +265 \\
\hline \multirow{2}{*}{ STS } & Cetate & 4814 & 5085 & +271 \\
\hline & Poiana Mare & 4896 & 5166 & +270 \\
\hline
\end{tabular}

Table 6. Differences between the locations on altitude $(\mathrm{m})$ of climate suitability classes during the 1991-2013 and 1961-1990 time periods at Romania level.

\begin{tabular}{|c|c|c|c|c|}
\hline \multirow{2}{*}{$\begin{array}{c}\text { Climate } \\
\text { suitability classes }\end{array}$} & \multicolumn{4}{|c|}{ Differences (km) } \\
\cline { 2 - 5 } & Min & Max & Range & Mean \\
\hline UNS & +96 & 0 & -96 & +129 \\
\hline WTW & +105 & +182 & +77 & +131 \\
\hline QWW & +36 & +181 & +145 & +80 \\
\hline QRW & 0 & +130 & +130 & +30 \\
\hline
\end{tabular}

also demonstrated by the fact that the climate change does not manifest homogeneously at the regional level, which determines topoclimates with particular suitability for the wine production, higher or lower than the region's average to which they belong. In order to establish the climate suitability type determined by the new climatic context, a fine scale analysis of vineyard climate is required.

Statistical analyse of differences occured in the spatial distribution of climate suitability zones at Romania level during the two time periods reveal their major shifts on altitude and latitude (Tables 6 and 7).

In the case of altitude shifts, the spatial range of the UNS area narrowed by $96 \mathrm{~m}$ while its location on altitude increased by $129 \mathrm{~m}$; the spatial range of the WTW, QWW and QRW climate suitability types increased by 77
Table 7. Differences between the latitudinal coordinates of the climate suitability classes during the 1991-2013 as compared to 1961-1990.

\begin{tabular}{|c|c|c|c|c|}
\hline \multirow{2}{*}{$\begin{array}{c}\text { Climate } \\
\text { suitability classes }\end{array}$} & \multicolumn{4}{|c|}{ Differences (km) } \\
\cline { 2 - 5 } & Min & Max & Range & Mean \\
\hline UNS & +1.8 & -3.9 & -5.7 & -3.92 \\
\hline WTW & +1.2 & -1.8 & -3.0 & +89.0 \\
\hline QWW & +77.0 & +55.4 & -21.6 & +101.0 \\
\hline QRW & 0.0 & +127.3 & +127.3 & +45.0 \\
\hline
\end{tabular}

Table 8. The structure of climate suitability for wine production in Romania during the 1961-1990 and 1991-2013.

\begin{tabular}{|c|c|c|}
\hline \multirow{2}{*}{$\begin{array}{c}\text { Climate } \\
\text { suitability class }\end{array}$} & \multicolumn{2}{|c|}{$\%$ in the total area } \\
\hline & $1961-1990$ & 1991-2013 \\
\hline QRW & 21.20 & 36.57 \\
\hline QWW, RTW & 16.24 & 16.13 \\
\hline WTW, SW, WD & 25.47 & 20.28 \\
\hline Unsuitable & 37.07 & 27.01 \\
\hline - & 100 & 100 \\
\hline
\end{tabular}

to $145 \mathrm{~m}$, while their location on altitude shifted by 30 to $131 \mathrm{~m}$.

Regarding the location on latitude of climate suitability classes, statistical analysis reveals (Table 7): a $5.7 \mathrm{~km}$ narrowing of the UNS spatial interval for the recent time period as compared to the 1961-1990 time period and the shift of its minimum altitude limit by $1.8 \mathrm{~km}$ to $\mathrm{N}$ as compared to 1961-1990; narrowing of the average spatial range of the WTW and QWW climatic zones by 3 to $21.6 \mathrm{~km}$, along with the northward shifts of the minimum latitude by 1.2 to $77 \mathrm{~km}$; widening of the spatial range of the climate-suitability zone for QRW by $127 \mathrm{~km}$ and a $45 \mathrm{~km}$ northern shift of its average location.

Simultaneously with these major spatial and structural shifts, the structure of area with climate suitable for wine production is changing in Romania in an absolutely advantageous way for the wine production (Table 8). The area with climate unsuitable for wine production decreased by $10 \%$, from $37.07 \%$ between $1961-1990$ to $27.1 \%$ between 1991-2013; the area with climate suitable for WTW, SW and WD diminished from $25.47 \%$ to $20.28 \%$; the area with climate suitable for QWW remained quite stable at $16 \%$ of the total; and the area with climate suitable for red wine production increased by $15 \%$, from $21.2 \%$ between 1961-1990 to 36.57\% between 1991-2013.

\section{Conclusions}

The impact of climate change on Romania's viticulture is a major one. According to the results of our study, the changes in temperature, sunshine duration and precipitation averages in the context of climate change determined the expansion of climatically suitable area for wine grape growing in Romania, the changes in regional climate suitability structure and spatial distribution. New climatically suitable areas for wine grape growing have emerged, most of them in the Transylvanian Plateau, the coldest region of the country, while the climate suitability of traditional wine regions and vineyards has changed in most cases in a positive way. The areas climatically suitable for white table wine production in the past have become climatically suitable for quality white wines production; areas suitable for quality white 
wines have evolved to ones suitable for red table wine and quality red wines; while areas traditionally suitable for quality red wine production keep their potential, but they are experiencing increases in heliothermal resources that makes them resemble to areas specialized in table grape production. Climatic suitability for wine grape growing shifts on altitude and latitude to cooler areas, respectively to higher elevations and to northern latitudes. The developments revealed by this study are consistent with those revealed or predicted based on climate models up to date. On the other hand, we notice important local variations of suitability for wine grape growing, which manifest in the context of climate change and which are not revealed by regional analysis, requiring a fine scale analysis of suitability of the vineyard climate. The results of this study can be used to develop strategies for Romanian viticulture adaptation to climate change, by adapting vineyard variety assortments and by a judicious placement of the new grapevine plantations.

\section{References}

[1] IPCC, Contribution of working group I to the fifth assessment report of the intergovernmental panel on climate change (Cambridge University Press, 2013)

[2] L.B. Webb, P.H. Whetton, E.W.R. Barlow, Aust J Grape Wine Res. 13, 165-175 (2008)

[3] VO Sadras, M.A Moran, M. Bonada, Aust J Grape Wine R 19, 95-106 (2013)

[4] G.V. Jones, R.E. Davis, Am J Enol Vitic 51, 249-261 (2000)

[5] R.R. Nemani, M.A. White, D.R. Cayan, G.V. Jones, S.W. Running, J.C. Coughlan, Clim Res, 19, 25-34, doi: 10.3354/Cr019025 (2001)

[6] G.V. Jones, M.A. White, O.R. Cooper, K. Storchmann, Clim Change 73, 319-343 (2005)

[7] L. Hannah, P.R. Roehrdanz, M. Ikegami, A.V. Shepard, M.R. Shaw, G. Tabor, L. Zhi, P.A. Marquet, R.J. Hijmans, Proc Natl Acad Sci USA 110, 6907-6912 (2013)

[8] H. Fraga, A.C. Malheiro, M.J. Mouthino Pereira, J.A. Santos, Int J Biometeorol 57, 909-925 (2013)

[9] M. Moriondo, G.V. Jones, B. Bois, C. Dibari, R. Ferrise, G. Trombi, M. Bindi, Clim Change 119, 825-839 (2013)

[10] OIV, State of the Vitiviniculture World Market http://www.oiv.int/en/technical-standardsand-documents/statistical-analysis/stateof-vitiviniculture (2016)
[11] A.E. Croitoru, A. Piticar, Int J Climatol 33, 1987-2001 (2013)

[12] M.V. Bîrsan, A. Dumitrescu, DM. Micu et al., Nat Hazards 74, 1899 (2014)

[13] R. Bojariu, V.M. Bârsan, R. Cică, L. Velea, S. Burcea, Al. Dumitrescu et al., Schimbările climatice - de la baze fizice la riscuri şi adaptare. Administraţia Naţională de Meteorologie (Printech Bucureşti, 2015)

[14] Busuioc, A. Dobrinescu, M.V. Bîrsan, A. Dumitrescu, A. Orzan, Int J Climatol 35, 1278-1300 (2015)

[15] A. Dumitrescu, R. Bojariu, M.V. Bîrsan, L. Marin, A. Manea Theor Appl Climatol 122, 111-119 (2014)

[16] M. Bucur, L. Dejeu, Bulletin UASMV Horticulture 73, 126-134 (2016)

[17] L.M. Irimia, C.V. Patriche, H. Quenol, L. Sfâcă, C. Foss, Theor Appl Climatol. doi: 10.1007/s00704017-2033-9 (2017)

[18] Şt. Teodorescu, A.I. Popa, G. Sandu Oenoclimatul României (Scientific and Encyclopedic Press, Bucharest, 1987)

[19] M.C. Peel, B.L. Finlayson, T.A. McMahon, Hydrol Earth Syst Sci 11, 1633-1644 (2007)

[20] EEA, http://www.eea.europa.eu/data-andmaps/data/clc-2006-vector-data-version-2 (2006)

[21] A. Dumitrescu, M.V. Bîrsan, Nat Hazards 78, 1045-1063 (2015)

[22] M. Oşlobeanu, M. Macici, M. Georgescu, V. Stoian Zonarea soiurilor de viţă de vie în România (Ceres Press, 1991)

[23] LM Irimia, CV Patriche, H Quenol, J Int Sci Vigne Vin 48, 145-167 (2014)

[24] W.M. Kliewer, Lider L.A. J Am Soc Hortic Sci 95, 766-769 (1970)

[25] N.K. Dokoozlian, W.M. Kliewer, J Am Soc Hortic Sci 121, 869-874 (1996)

[26] Mesterházy, R. Mészáros, Pongrácz R. 118, 193-206 (2014)

[27] L.M. Irimia, Biologia, ecologia şi fiziologia viţei de vie (Ion Ionescu de la Brad Ed, 2012)

[28] E. Duchêne, C. Schneider, Agron Sustain Dev 25, 93-99 (2005)

[29] M. Stock, F.W. Gerstengarbe, P.C. Werner, Acta Horticulturae 689, 29-40 (2005)

[30] M. Kryza, M. Szymanovski, M. Blas, Theor Appl Climatol 122, 207-218 (2015) 